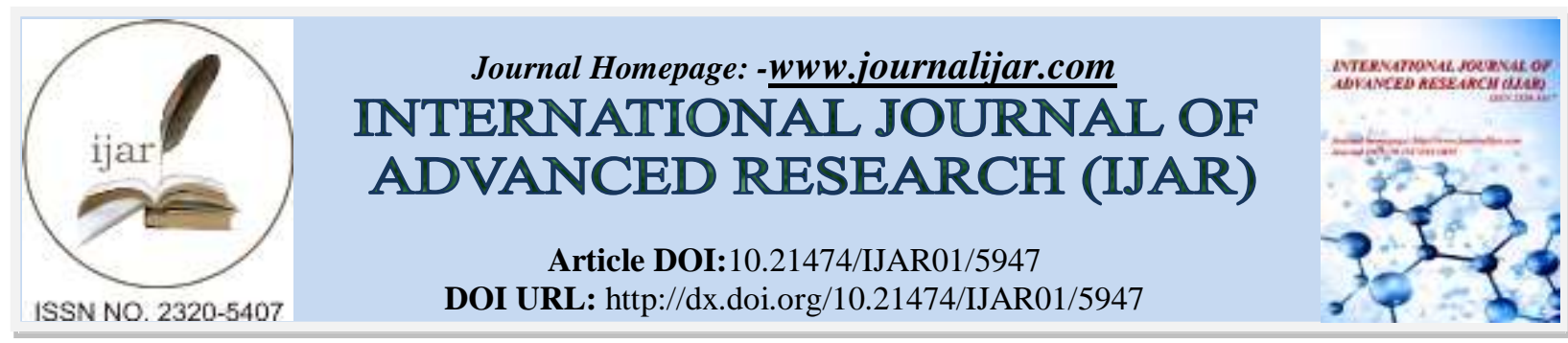

RESEARCH ARTICLE

\title{
THE RECRUITMENT TO FILL THE POSSITIONOF THE INDONESIAN CIVIL SERVICE APPARATUS (A DIGNIFIED JUSTICE THEORY PERSPECTIVE).
}

Agung Wisnu Barata ${ }^{1}$, Prof. Dr. Teguh Prasetyo ${ }^{2}$ and Dr. H. Jawade Hafidz, SH, MH ${ }^{3}$.

1. Doctoral Student at the Faculty of Law Universitas Islam Sultan Agung Semarang.

2. SH, M. Si, Commissioner DKPP-RI.

3. Lecturer in Law Faculty of Law Universitas Sultan Agung Semarang.

\section{Manuscript Info}

\section{Manuscript History}

Received: 02 October 2017

Final Accepted: 04 November 2017

Published: December 2017

\section{Key words:-}

Pancasila, The State Apparatus, Dignified Justice Theory.

\section{Abstract}

Philosophically, or in the same term according to the theory of dignified justice, the Indonesian Jurisprudence, the position of Pancasila as a philosophical foundation in the life of the state and nationality contains a consequence that in all aspects of statehood and national life including the Indonesian legal system are based on the values derived from Pancasila as the First Principle (KesepakatanPertama). The method of recruitment to fill the positions of the State Civil Apparatus (ASN) in Indonesia is not in accordance with Pancasila Law Philosophy if the method is based merely on the ideals of openly and competitively principles, since those ideals are the ideals of liberalism/invidualism. In reconstruction, this research would suggest that the bad method of recruitment to fill the possition of the State Civil Apparatus (ASN) must be accompanied with the ideals method contained in the the Philosophy of Pancasila.

Copy Right, IJAR, 2017, All rights reserved.

\section{Introduction:-}

The Unitary State of the Republic of Indonesia is a law state (negara hukum). Although the sovereignty is in the hands of the people and it is carried out in accordance with the Constitution. From the dignified justice theory, i.e. the legal philosophy or the Indonesian Jurisprudence this fundamental principle is derived from Pancasila, the Indonesian five tenets; particularly the third tenet which is formulated as a people led by wisdom and policy in the representative deliberation. It is therefore Indonesia is considered as a democratic constitutional state.

In this term it is obliged to carry out the development of national law which is done in a planned, integrated, and sustainable in the legal system, called Pancasila Legal System. This Indonesian national legal system guarantees the protection of the rights and obligations of all Indonesian people. All of the rights and obligations formulated in the legal system must be based on Pancasila and the 1945 Constitution of the State of the Republic of Indonesia.

Meanwhile, in general the typology of the modern positive law system in the world is allegedly rife with administrative bureaucracy. This is consequence of a modern state law in a welfare state. This trend has emerged as a conical legal system forming a legal pyramid from basic law at its top to laws at the applicative level at the bottom. 
If therefore the pyramidal system must be repaired or reformed, aspects to be reformed are consists of legal substances, legal structures, and the culture of law, either in the process of law making, the application of the law or implementing the law or itsenforcement process.

All of these must respond and accommodate living law as an expression of the values, norms, institutions and legal traditions that live and thrive in the society, and in the Indonesian system all are derived from Panccasila. This is the nature of law from the philosophy of law called the dignified justice theory developed by TeguhPrasetyo. The process of reformation is characterised by the fact that the law is an institution that constantly builds and transforms itself according to the dicatete of the law to a better level of perfection. The purpose of the quality perfection is directed into factors such as among other things justice, welfare, concern for people or humanity as created in the image of the Almighty God. SatjiptoRahardjo says this is the nature of the law that is always in the process of being.

As stated above and several times in this Journal, for the Indonesian nation Pancasila is regarded as the basis of philosophy for the life of its society, the nation and the republic state. Therefore, to achieve the goals in the life of nationality and state especially in carrying out development and renewal it must base on a framework that comes from the values of Pancasila.

Philosophically, or in the same term according to the theory if dignified justice, the Indonesian Jurisprudence, the position of Pancasila as a philosophical base in the life of the state and nationality contains a consequence that in all aspects of statehood and national life including the Indonesian legal system are based on the values derived from Pancasila as the First Principle (Kesepakatan Pertama).

The objective reality of Pancasila philosophy for the Indonesian nation is a core value for the legal system of Indonesia. The values contained in Pancasila is a source of value for the elaboration of legal norms to further regulating the life of society, the nation and the republic state.

As it has been generally understood that in the world of science there are two different views related to the relationship of knowledge with value. Firstly, science is value free. According to this view, science must be separated from all of the religious values, ethics and certain customs which are moral guidelines. In the legal philosophy literature the prevalence of this view is shared by legal positivism, which promoting utilitarianism, sociological jurisprudence school, and legal realism philosophy.

Second, Scientists who believe that science is bound by values (value bound) including the science of law. In relation to the legal science in Indonesia which is philosophically based on the philosophy of Pancasila, it is certain that Indonesia is a value-bound science view. However, from the perspective of the dignified justice theory the values or virtues as such must be all the values and virtues within the Law.

Thus it can be said that all laws in Indonesia must be based on the values of Pancasila, and this is the Pancasila legal philosophy in the eyes of the dignified justice theory. Consequently, from the dignified justice theory perspective all the laws and regulations which govern the State Civil Apparatus (ASN) must also be guided by the Philosophy of Pancasila Law.

With regards to the filling or recruitment of the positions of the State Civil Apparatus (ASN) in Indonesia, the law which govern this is mainly the Law Number 5 of 2014 on State Civil Apparatus (ASN).

In connection to it, in oreder to implement this Law, there is another regulation made for it. It is the Government Regulation Number 11 of 2017 on the Civil Service Management. There are several principles that can be found in the desideratum or consideration stipulated for the Law Number 5 of 2014 on The Civil State Apparatus (ASN). All of that considerations are stated as follows:

Firstly, it is stated that in the context of the implementation of the nation's ideals and the realization of the state's objectives as stated in the preamble of the 1945 Constitution, it is necessary that state civil apparatus be with integrity, having a professionalism, neutral and free from political intervention, clean of corruption or corruptive behaviour, collusion and nepotism practices, able to organize public service for the community and able to perform 
the role as an adhesive element of the unity of the nation. This last term is the fundamental term based on Pancasila, the third tenet and the 1945 Constitution of the State of the Republic of Indonesia.

Secondly, it is also stated in the consideration of the Act, that the implementation of civil state apparatus management must be based on the competencies and qualifications required by the positions. It must be the competencies and qualifications of the candidates in the recruitment, appointment, placement and promotion of the position which is in line with good governance principle.

Thirdly, it is stipulated in the Act that in order to realize the civil state apparatus as part of bureaucratic reform, it is necessary to stipulate the civil apparatus of the state as a profession having the obligation to manage and develop itself and must be accountable for its performance and apply the merit principle in the management of civil state apparatus.

Fourthly, it is related to the Law Nomber 8 of 1974 on the Principles of Personnel as amended by the Law Number 43 of 1999 on the Amendment to Law Number 8 of 1974 on the Principles of Personnel that there must be values which are in accordance with national demands and global challenges. Therefore the Law is in need of reform.

The method or epistimological aspect used in the recruitment to fill the position of the State Civil Apparatus (ASN) is open and competitive. This open and competitive method stated on the Act needs to be reviewed from the philosophy of Pancasila, or as suggested by Professor TeguhPrasetyo as fundaentals to fill the position The State Civil Apparatus (ASN). We therefore argued that this method of recruitment is compatible with the philosophy of Pancasila Law. As mentioned above, the Pancasila is the Foundation or the Philosophy of the Nation of Indonesia.

Regretrully, one of Indonesian constitutional law experts, named JimlyAsshiddiqie, a professor has argued that the method stated above is indication or the phenomenon of liberalization of public officials recruitment system that occurs today in the Indonesian system. Asshiddiqie argued that on the one hand the method has a positive impact in the context of modernization of public management system, but on the other hand it can also be bad. Therefore, Professor Asshiddiqie added that a thorough evaluation on the kind of public office method of recruitment needs to be transparent on its election by whom and for what purpose whether it is directly or indirectly.

Moreover, all such recruitment processes need to be organized and re-arranged in a complete and integrated manner, so that the recruitment system can serve as a standard working guideline in order to ensure the institutionalization process of inclusive and meritocratic public institutions.

A Second Focussed Group Discussion (FGD) conducted at Gajah Mada University has concluded, something which is in accordance with the Dignified Justice Theory that Pancasila in the laws and regulation governing the recruitment of the Civil State Apparatus must serve as criteria, indicators and benchmarks in it for the state organizers either in the legislative, executive, and judicial institutions. Refering to the background mentioned above, the root of the problem of this research is whether it is correct the recruitment to fill the position of the Civil State Apparatus (ASN) in Indonesia is in accordance with the dignified justice, a theory which is justified the Pancasila as the Indonesian Law Philosophy or the Indonesian Jurisprudence? The research is conducted to ascertain that proper and correct recruitment to fill the positions in Indonesia does indeed match with the Philosophy of Pancasila as the Indonesian First Agreement. The research could also be coined as a short of reconstruction on how to fill the gaps in the laws and regulation governing the recruitment system of the ASN.

\section{A Framework of the Pancasila Philosophy on The Law of ASN:-}

Philosophy, as it has been generally understood comes from a Greek word, which is divided into philean means to love and sophia means wisdom (wisdom). So philosophy means to love of wisdom. In order for a person to be wise, he must understand the world in which he lives. It is therefore philosophy is some times defined as one of human efforts to understand his world and exsistence. Philosophizing means to think, but this does not mean every thinking is philosophizing. Philosophizes is thinking with certain characteristics.

There are some characteristics of philosophical thinking: radical, universal (general), conceptual, coherent and consistent, systematic, comprehensive, free and responsible. All of these characteristic is the characteristic of the Dignified Justice Theory, the Indonesian Jurisprudence, a philosophical thinking or legal philosophical. It is also thought as traits or characteristics that distinguish it from other law theoretical framework. The Dignified justice 
theory is comprehensive and universal, fundamental or focused on basic or fundamental questions. Although it is speculative but critical reflective, and introspective.

From the perspective of the Dignified Justice Theory, to know the Pancasila as the ontological abstraction for analysis there are three steps. Firstly, it leaves things that just happen to happen and placing it as the object being analyzed. Secondly, it also select things that must be put as the object being analyzed; Thirdly, the result is that all that remains is the absolute core elements that must exist for the existence of the object being analyzed.That is the deep knowledge of the object being analyzed or the waht so alled the essence of the object being analyzed). The Dignified Justice Theory as a theoretical framework is simply perform the abstraction or the ontological of a thing being analysed by removing the Coincidence; and to be sure that what remains remains. And that the absolute must exist for the existence of what is analyzed.

From the Dignified Justice Theory as the framework of this research, the Philosophy of Pancasila stands as ontological postulate that belive that God exists, man exists. Man has a relationship with with God, with man (others and also with himself), and with objects (including the inorganic, vegatatif, and animal). That is what the three relations of human nature are all about.

The three relationships of human nature containd in the fifth principle of the Pancasila. The first precept of the One Supreme God is the incarnation of the human relationship with God, the second principle is Just and Civilized Justice is the manifestation of human relationships with human beings including himself, the third principle of the Unity of Indonesia is the manifestation of human relationships with his fellow human beings, the fourth precedence of the Democratic People by the wisdom of wisdom in deliberation/representation is the manifestation of human relationships with his fellow human beings, and the fifth principle of social Justice for all the people of Indonesia is the manifestation of human relationships with his fellow human beings and also with things. In all these relationships, man is the base.

Pancasila is a philosophy, the basic philosophy (philosofische grondslag) of independent Indonesia, which was founded on the State of Independent Independence Indonesia and eternal. The philosophy of Pancasila stems from kinship as the soul of our nationhood, making the Indonesian nation different from the ideas of individualism. Pancasila is rooted in human nature itself, that is love, the expression of human love towards neighbor and God.

This love in the Pancasila aim at the spirit of anti-oppression of humans by other humans. Pancasila is unearthed in Indonesia to lift the philosophy of mutual assistance that contains spiritual values, togetherness, caring, justice, and spirit of ideals with the welfare community. Pancasila as the philosophy of the state, placing the nation of Indonesia to be faithful to itself, developing his own personality in customs, state culture and in the life of the state.

Based on the values of Pancasila law can not be separated by religious which values is protected under the law. These values are the value of human nature, the value of unity and diversity of Indonesia, the value of democracy, and the value of justice in relation to the people and the nation of Indonesia. In addition, according to Pancasila law and society are not two entities to be separated. Law developed because of the demands of life under the law. Law is developed to create order in society according to the law.

Based on the understanding of the nature, then the definition of the recruitment of the State Administration of Civil State Administration (ASN) is the process of finding the best leaders to occupy positions of leadership in government agencies. It must be conducted with an open and competitive selection methods. The result is that leaders as servants which occupy leadership positions in government institutions and agencies with the function lead and motivate every employee the welfare of the society and the nation.

Thus, in the framework of the Dignified Justice Theory, the essence of rcruitment to fill the position of the Civil State Apparatus which is conducted openly and competitively is none other than the search for a servant leader. Determination method of searching for a leader will affect the results (output) obtained. This is the key in the analysis using Pancasila for analysing the method of finding the leader. In the ideals of Pancasila, the conceps such as openly and competitively must be in the spirit of kinship to be the essence of the philosophy which is kinship and harmony 
It would be proper to add that in the Pancasila as the Indonesian cosmology kinship is mostly preffered rather than individualism. In other words, although kinship and individuality are referred to as pairs, but the nature of kinship is superior. Indonesian society tends to feel comfortable life when they are united with the natural environment and the Creator, which is the Almighty God. Recognition and self-esteem as social beings only being part of the concept of teo-centric that tells people to do good to other human beings. In the perspective of the Dignity Theory of Justice, humans have to deal humanly with other human beings (nguwongke wong), not to think that human being is animals, such as political or economic animals. However, in Indonesia it is the sunatullah (kodrat) that harmony is sometimes cracked by a factor. Seeds of conflicts that reside in each individual sometimes expands in such a way as to instantly push the position, rights and existence of others.

To solve it, Indonesians, especially Javanese, when faced with problems will selected ways of settlement by highlighting social solidarity, compromise, deliberation (concilition) and soft approaches. All of these methods are always seen as the best way to resolve conflicts in the Javaanese society with the priority of restoring a harmonious life atmosphere. It can even be expressed that the deliberations are the main characteristic of Indonesian legal culture. When looking at history, the Indonesian nation in seeing the law is more focused on the behavior than to see the law as written text (legislation). Good law is religious behavior, which is always oriented towards harmony.

In contrast to individualism-liberalism that puts individuals in a strategic position and always favored. Individualism puts a person in the highest position, possesses an even strongest self-esteem. Such self-esteem is seen as an intrinsic value. Based on individualism, everyone is encouraged to be able to demonstrate the authority and autonomy of free and maximal thinking and acting.

In the field of law individualism tends to create domination of a certain individual over ohers. As the laws formed on the basis of individualism will always provide the opportunity, wider space as well as protection against the individual's privacy. As the purpose of self-exclusivity is the self-actualization. In individualism, selfdevelopment is permissible and legitimate through the conquest of others. There is even the understanding that the best people are the ones winning in the competition, because the essence of life itself is competition. In this context, the essence of the legal system that promote only the system of openly and competitively recruitment to fill the ASN possition must be prevented with the spirit of indivudualism, since it is not the soul of the family as taught by Pancasila.

Individualism cosmology teaches that conflict is part of a competition. The parties are free to choose on conflict resolution methods, procedures and techniques. If the parties want to resolve the conflict, then on the basis of litigation, and setting aside other alternative methods such as mediation or conciliation. The law in the individualism cosmology prevail the modern life dominated by individual. The parties to the conflict almost can no longer expect to gain substantial justice as in the cosmology of holism, but to the extent of formal justice, that is justice under the laws of law.

The incorrect determination of this individualism legal philosophy will have an operational or praxis effects in the provisions of the rule of law under its control. The well-developed harmony between ASN from the Pancasila perspective will be disintegrated and will further cause the disintegration of the nation because the individualism consider fellow ASN as friends to be competitors, whereas in Pancasila a fellow ASN is taught with kinship, mutual cooperation, tolerance and harmony. This will prevent a disintegration dangerous and for the interest of the Unitary State of the Republic of Indonesia (NKRI), In fact ASN is built to function as "the glue" of the nation and the State of Indonesia.

Based on the analysis of the Dignified Justice Theory or the Philosophy of Pancasila Legal System, therefore this research has found that the method of open and competitive selection values contained in the Law Number 5 of 2014 has been integrated with the ideals in the Pancasila as stated in Chapter IX, Article 108, Paragraph (3) and Paragraph (4) which reads that: the recruitment to fill of high leadership positions is carried out openly and competitively among civil servants with due regard to the requirements of competence, rank, education and training, track record, and integrity and other requirements in accordance with the provisions of legislation .

The recruitment formulated method to fill the positions of high leadership is conducted openly and competitively at the national level or between districts/cities in one province. The word openly and competitively alone will be considered as based on liberal/indvidual without Pancasila values. It would then be considered as not in accordance 
with Pancasila Law Philosophy. Therefore it needs to be reconstructed so that it will be in accordance with Pancasila Philosophy, among others is consensus.

\section{Conclusion:-}

Based on the study of the Philosophy of Pancasila Law on the method of recruitment to fill the positions of the State Civil Apparatus (ASN) in Indonesia, the positioning of the State Civil Servant (ASN) in Indonesia is not in accordance with Pancasila Law Philosophy if the method is based merely on the ideals of openly and competitively principles, since those ideals are the ideals of liberalism/invidualism;

In reconstruction, this research would suggest that the bad method of recruitment to fill the possition of the State Civil Apparatus (ASN) must be accompanied with the ideals method contained in the the Philosophy of Pancasila, the filling position of the State Civil Apparatus (ASN) in Indonesia needs to be reconstructed to be in accordance with Pancasila Law Philosophy, i.e. it must be not simply open and competive as word formulated in the Law Number 5 of 2014, Chapter IX, article 108, paragraph (3) and paragraph (4) but being replaced by words that are representing values and virtues of the Pancasila.

\section{Bibliography:-}

1. Asshiddiqie. Jimly, makalah Liberalisasi Sistem Pengisian Jabatan Publik, disampaikan dalam rangka konferensi hukum tata Negara di UNAND, Padang, September 2001.

2. Lawrence M. Friedman, The Legal System, A Social Science Perspective, Russel Sage Foundation, New York, 1975, Terjemahan M. Khozim, Sistem Hukum: Perspektif Ilmu Sosial, Nusamedia, Bandung, 2009.

3. Kelsen. Hans, General Theory of Law and State, Translated by Anders Wedberg, Russel and Russel, New York, 1961.

4. Kaelan, Liberalisasi Ideologi Negara Pancasila, Paradigma, Yogyakarta, 2015.

5. Lev. Daniel, Judicial Institusions and Legal Culture in Indonesia (Claire Holt, ed), Itahaca: Cornell UniversityPress, 1972.

6. Moch. Marsinggih MD, Pokok-pokok Pikiran Pencerahan Pancasila, Simphoni Kebangsaan, Slawi, 2012.

7. Rekomendasi FGD Pakar II yang diselenggarakan Pusat Studi Pancasila (PSP-UGM) kerjasama dengan Universitas Pancasila Jakarta, 09 November 2013.

8. Satjipto Rahardjo, Hukum Progresif Hukum yang Membebaskan,Jurnal Hukum Progresif, Vol. 1/No. 1/April 2005, PDIH UNDIP, Semarang.

9. Soerjono Soekanto, Beberapa Permasalahan Hukum dalam Kerangka Pembangunan di Indonesia, UI-Press, Jakarta, 1983.

10. Sudjito bin Atmoredjo, Tinjauan Yuridis-konstitusional Konsistensi Nilai-Nilai Pancasila dalam UUD 1945 dan Implementasinya, PSP Press, Yogyakarta, 2010.

11. Sunarjo Wreksosuhardjo, Filsafat Pancasila Secara Ilmiah dan Aplikatif, Andi Offset, Yogyakarta, 2004.

12. Teguh Prasetyo dan Abdul Halim Barkatullah, Filsafat, Teori, dan Hukum Pemikiran Menuju Masyarakat yang Berkeadilan dan Bermartabat, Rajawali Press, Jakarta, 2013.

13. Undang-Undang Dasar Negara Republik Indonesia Tahun 1945.

14. Undang-Undang Republik Indonesia Nomor 5 Tahun 2014 tentang Aparatur Sipil Negara (ASN). 